\title{
EXPLORING THE BACKYARD OF nCOVID: DETERMINANTS OF DEATH TOLL IN PANDEMICS
}

\author{
Rajesh Guptal', Smita Trivedi2 \\ 1. National Academy of Indian Railways, \& Indian Institute of Management-Kashipur, India \\ 2. Maharaja Sayajirao University, Vadodara, India
}

Correspondence: indiwindy@gmail.com

\begin{abstract}
Heterogeneity in number of deaths in different countries during the ongoing nCOVID crisis challenged us to look for determinants of pandemic death toll across the world. Using the past two decades data of pandemic deaths in the world, this study considered if engagement in international trade, health care expenditure and population density have any impact on the pandemic death toll. Using linear regression model controlled for types of disease, we not only found trade significantly impacting death toll, but also surprisingly found positive correlation between share of healthcare expenditure in GDP and fatalities in pandemics. Our findings suggest that policy intervention is required for mitigating health impacts of trade and 'tweaking' the health expenditure towards pandemic prevention.
\end{abstract}

\section{KEYWORDS}

pandemic, global trade, healthcare

JEL Classification: F10, F13, 118, Q18

\section{INTRODUCTION}

The recent eruption of nCOVID pandemic has seen 2,379,975 nCOVID-19 cases and 163,921 deaths as on the 19th April2020 [1] is not the first pandemic in human history. Death toll in pandemics have been more horrific than nCOVID so far. To count a few of them, Black Death of 1347 killed 75 million, Spanish Flu of 1918 killed 100 million and Asian Flu of 1957 killed 2 million people world over.[2]
Unfortunately, nCOVID may not be the last pandemic, as virus strains continue to evolve. [3] Since history throws light on the factors affecting pandemic spread [4], there was no greater need for studies on the subject than now. Pandemics are occurring more frequently with the passage of time, and this increase is observed to be concomitant with the increase in economic activity such as trade and travelling.[5] While mode of transmission of such disease outbreaks remains ambiguous, [6] studies are attempting to bring some clarity on the channel which increased economic activities might be correlated with disease outbreaks.

The recent eruption of nCOVID pandemic has seen 2,379,975 nCOVID-19 cases and 163,921 deaths as on the 19th April2020 [1] is not the first pandemic in human history. Death toll in pandemics have been more horrific than nCOVID so far. To count a few of them, Black Death of 1347 killed 75 million, Spanish Flu of 1918 killed 100 million and Asian Flu of 1957 killed 2 million people world over.[2] Unfortunately, nCOVID may not be the last pandemic, as virus strains continue to evolve. [3] Since history throws light on the factors affecting pandemic spread, [4] there was no greater need for studies on the subject than now. Pandemics are occurring more frequently with the passage of time, and this increase is observed to be concomitant with the increase in economic activity such as trade and travelling. [5] While mode of transmission of such disease outbreaks remains ambiguous, [6] studies are attempting to bring some clarity on the channel which increased economic activities might be correlated with disease outbreaks. 
International trade, which means integration of domestic economy with the world economy is unavoidable as it is quintessential to growth. [7] Apart from impact on economic conditions such as growth, poverty and financial development, trade has been studied for impact on biodiversity, [8] environment [9] and health. [10] Overall impact of population density was dealt with

PANEL 1. TRADE AS \% OF GLOBAL GDP

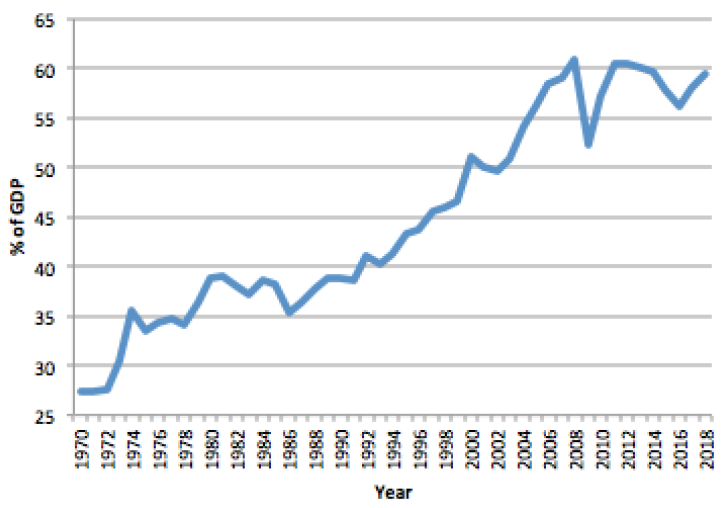

PANEL 3. GLOBAL HEALTH EXPENDITURE (\% OF GDP)

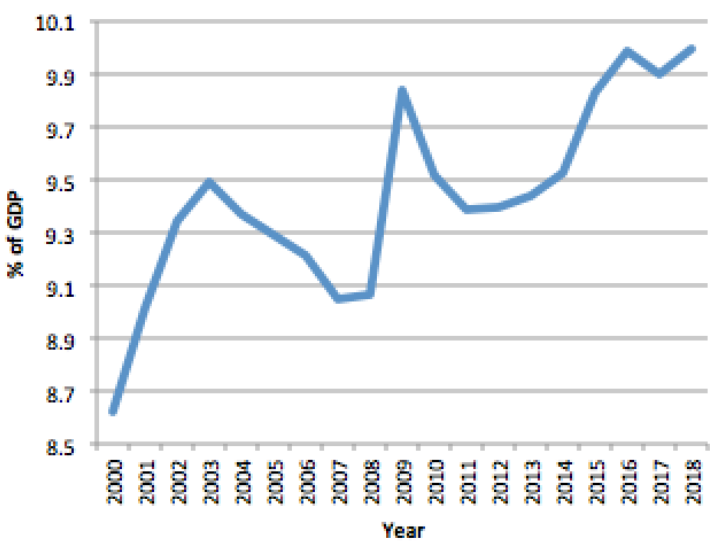

It is apparent that trade, population density and healthcare expenditure, all have increasing trends. The question is how these factors impact fatalities in pandemics. Surprisingly, studies on pandemic impact on either trade, population density or health-expenditure are conspicuous by absence. This question is important since response to pandemics has to be decided with global cooperation in the wake of capacity imbalance.[16] We study impact of global trade, health care expenditure and population density upon virus-borne and bacteria-borne pandemic deaths of the last two decades. We contribute by doing this first such study, to the best of our knowledge. comprehensively by Ehrlich and Holdren [11] and environment impact of the same was also taken up. [12] Health expenditure has been found to be impacting inequality, [13] economic growth [14] and of course health outcomes.[15] Trend of trade, population density and healthcare expenditure globally is explained in following panels:

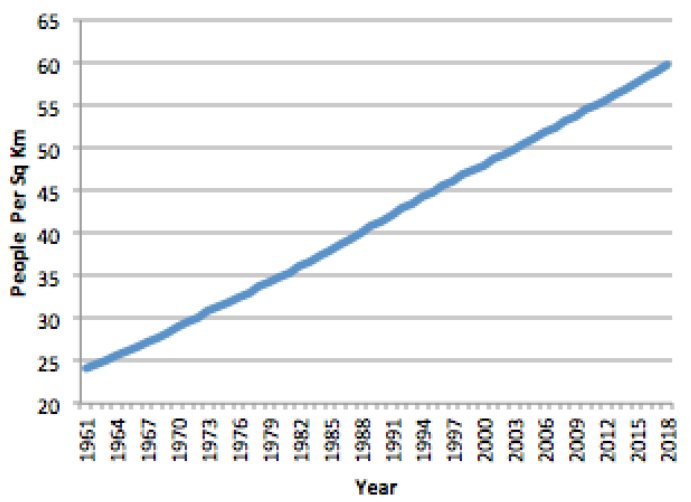

PANEL 4. GLOBAL HEALTH EXPENDITURE (US\$ /CAPITA)

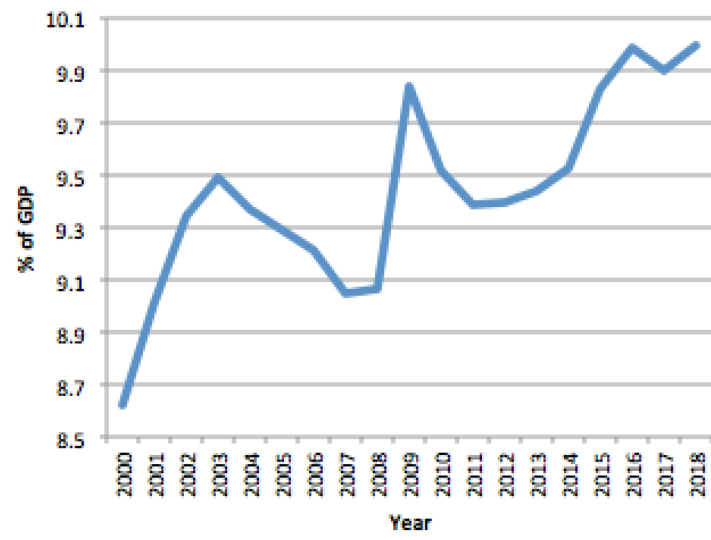

Our findings suggest that two key policy interventions are required: one for mitigating health impacts of trade and second for 'tweaking' the health expenditure towards pandemic prevention. Results of our model indicate a positive correlation of trade and (surprisingly) negative correlation between share of healthcare expenditure with death toll in pandemics.

The structure of the paper is the following: Section 2 reviews the existing literature on nexus between disease outbreaks and global trade integration. Section 3 entails the need of such analysis. Section 4 describes the methodology including data sources, model specification and 
econometric methods. Section 5 discusses the findings; followed by the concluding remarks in Section 6 .

\section{LITERATURE REVIEW:}

Literature on pandemics is profound in the natural sciences. Emergence and re-emergence of zoonotic infections by different influenza virus has been discussed for genetic evolution by Taubenberger and Kash. [17] Influenza pandemics like Spanish (H1N1), Asian (H2N2) and
Hongkong (H3N2) have been discussed for genetic patterns by Kilbourne. [18] Natural science studies like these have immense value since vaccination is the final saviour in such pandemics. [19]

Since disease outbreaks have become globalised [20] and frequent, [21] literature in social science has also become populated in the recent past. The literature on pandemics spread and economic activity nexus can be divided into two broad streams as depicted in the Figure 1 below:

\section{FIGURE 1. TWO STREAMS OF LITERATURE ON ECONOMIC ACTIVITY AND PANDEMICS}

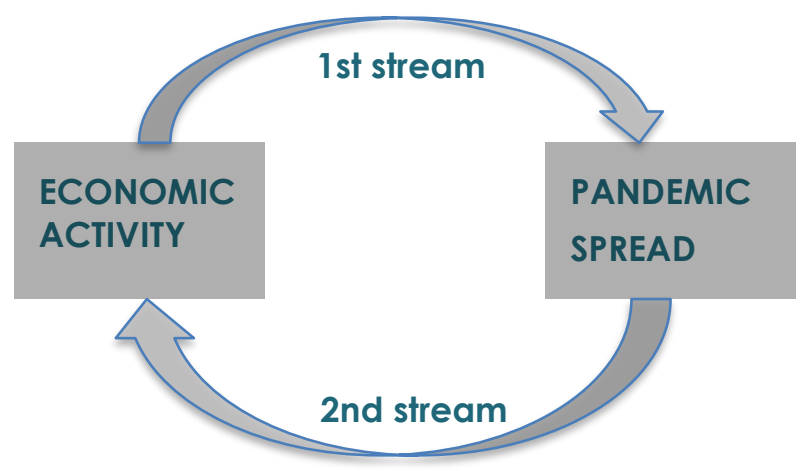

Literature on first stream (impact of economic activity on pandemics spread) is scarce compared to the second stream (impact of pandemics spread on economic activity). Our study belongs to the first stream. The 1918 influenza epidemic motivated much research on determinants of pandemics spread and Taubenberger \& Morens [17] can be termed as the seminal paper in this field. Around the same time, the question of impact of trade on child health has been discussed for many countries. [23] The role of administration in bioterrorism has been discussed for many countries. [24] The risk analysis for China has been done in relation to Nipah virus outbreak.[25] Most of the studies have been lacking in either control variables or the number pandemics included like diarrhoea, chicken pox and flu were included in a study examining impact of economic activity upon disease spread.[26] We found that determinants of HIV spread have been abundantly discussed in Hunt, [27] Altman [28] and Kieh \& Jr, [29] but other diseases have had less attention in the literature. The literature is not profound on the determinant side also, like Hosseini et al [30] found air travel and livestock export positively correlated with pandemic spread, but did not examine factors like healthcare expenditure in the study.
While there are many studies on the impact of disease outbreaks on the economy, especially after NCOVID, [31] literature on determinants of pandemics is scarce, to best of knowledge of the authors', and this paper attempts to fill this gap.

We should not leave this literature review without mentioning the important stream of response towards pandemics. The prescription paper [32] highlighted weaknesses and strengths of approaches for drug-makers, Osterholm [33] highlighted that the world is under-prepared for dealing with pandemics. Enemark [34] argued that every country needs to consider virus borne outbreaks in other countries as "their own". Thus, literature on determinants of pandemic spread, a stream to which our study belongs, is very relevant in the present context of nCOVID crisis.

\section{METHODOLOGY}

\section{DATA AND METHOD:}

To investigate the question what determines the mortality rate due to pandemics, the candidates for capturing the damage are: number of lives lost due to disease (death toll) 
and number of people infected (caseload). In our study, the death toll was chosen as the dependent variable instead of caseload because of two reasons: one, there could be misreporting in caseload data and second, death toll captures the effect of healthcare expenditure.

We use panel data for 50 pandemics that raged the world during 1990 to 2019. There were pandemics before this period also, but this period was found suitable for study as frequency of pandemics was higher during this period indicating increased vulnerability.[35] Also, since the world became more and more open for trade during this period, [36] we were motivated to probe if there is any impact of trade on pandemic death toll during the period. Data and source are as in Table 1.

As multiple linear regression models are widely used in healthcare literature, [43-45] we also use the multivariate linear regression model in our study.

TABLE 1. VARIABLES AND DATA SOURCES
Our model specification is as follows:

$$
\begin{aligned}
& \text { DPCPY }=a+\beta 1 \text { TGDPs }+\beta 2 \mathrm{HCPC}+\beta 3 \mathrm{PDEN}+\beta 4 \\
& \mathrm{HCGDP}+\beta C X c+\mu 1 \ldots \ldots \ldots \text { (1) }
\end{aligned}
$$

Where TGDP, HCPC, PDEN and HCGPD are main variables and $\mathrm{Xc}$ are control variable for diseases. Trade is one of the main explanatory variables, which we want to study. Population density is the obvious choice for explanatory variable as disease spread and fatality rate will be impacted by how closely people are settled.[46] Percapita healthcare expenditure and percentage share of GDP in healthcare capture the granularity of healthcare expenditure. Since fatality rates vary for types of diseases, [47] we control for the type of disease using dummy variables for different diseases in our model. Variables studied are summarized as Table 2.

\begin{tabular}{llll} 
VARIABLE & DEFINITION & SOURCE & REFERENCES \\
\hline DT & Death toll in disease outbreaks & World Health Organization & Floret et al. (2006) \\
& per capita per year & (WHO) database & Constantinescu et \\
TGDP & Trade as percentage of GDP & World Integrated Trade & al.(2020) \\
& & Solutions (WB) database & Reeves et al. (2014) \\
HCPC & Healthcare expenditure in \$per & World bank database & Hathi et al. (2014) \\
PDEN & capita & & Davoodi et al. (2010) \\
& sq. km of land area & World bank database & \\
\hline
\end{tabular}

TABLE 2. DESCRIPTIVE STATISTICS

\begin{tabular}{lllll} 
VARIABLE & MEAN & MIN & MAX & STD. DEV. \\
DT & 10.85 & 0.001 & 262.4 & 42.39 \\
TGDP & 61.29 & 20.08 & 209.49 & 39.68 \\
HCPC & 1233.36 & 24.62 & 8335.87 & 2043.64 \\
PDEN & 126.82 & 2.82 & 454.93 & 140.64 \\
HCGDP & 6.92 & 2.56 & 20.4 & 3.71 \\
\hline
\end{tabular}


We observe from the above table the heterogeneity in country variables and the disease death toll as well. We have run the linear regression duly including the disease control variables.

\section{RESULTS}

Regression results are presented in the Table 3 and our explantory variables could explain $43 \%$ of the variation in the dependent variable. Though coefficients of healthcare expenditure per capita and population density are having signs as expected (negative and positive respectively), they are not found significant in our study. We find significant impact of share of GDP spent upon healthcare. Interestingly, each additional \% of GDP spend upon healthcare results into about 7 more death per capita in a year due to pandemics in a country.

TABLE 3: RESULTS OF REGRESSION

\begin{tabular}{|c|c|c|}
\hline & \multicolumn{2}{|c|}{ DT } \\
\hline & Coeff & p value \\
\hline intercept & -67.73 & 0.003 \\
\hline TGDP & 0.428 & 0.017 \\
\hline НСРС & -0.006 & 0.143 \\
\hline PDEN & 0.053 & 0.261 \\
\hline HCGDP & 6.97 & 0.01 \\
\hline R Square & \multicolumn{2}{|c|}{0.639} \\
\hline Adj R Square & \multicolumn{2}{|c|}{0.435} \\
\hline F Statistic & \multicolumn{2}{|c|}{$3.13\left(^{* *}\right)$} \\
\hline
\end{tabular}

\section{IMPACT OF TRADE:}

We found the coefficient of trade as a percentage of GDP significant and positive. This means countries with higher dependence of their economy on trade are likely to be more vulnerable to pandemics. This empirical finding is first ever in the literature (to the best of our knowledge) and thus our contribution to the literature. This also means that with increasing trade opennes in the world, perhaps the necessary guard against the danger of pandemics has been missed by countries.

\section{IMPACT OF HEALTHCARE EXPENDITURE:}

It is worthwhile to underscore here that coefficient for healthcare expenditure per capita is negative (which means more per capita expenditure results into less deaths in pandemics) but the coefficient of healthcare expenditure as a percentage of GDP is positive ( which means countries spending more of their GDP on health goes against pandemic death prevention). The former is in agreement with the findings that argue for universal coverage for primary healthcare. [48] But the latter should lead to much needed further research on prioritisation of healthcare expenditure. These findings are important for developing countries as they have low income elasticities of health expenditure.[49] As the 2020 nCOVID crisis has highlighted healthcare expenditure needs re-design so as to deal with pandemics.

\section{IMPACT OF POPULATION DENSITY:}

We find that densely populated countries are singificantly more impacted by pandemics. As seen from Panel 4 of the Section-l, global population density has more than doubled in last few decades, this finding is on the expected lines, but empirical statement of relationship with pandemics is brought out in our study. This calls for re-design of urban clusters for saving lives from pandemics. This is a huge challenge as incease in poulation density is concomitant with economic growth.[50] Since healthcare reform with community engagement [51] has the potential to address such challenges, more study in this direction will be of great value. It is time that research for pandemic-resistant urban spaces stems from the literature.

Infectious disease outbreak happens due to human-tohuman contacts across geographies [52] and if we go by the argument that such contacts are random, [53] we can assume pandemics as random experiments of diseasecausing virus. Though our regression results only mean correlation and more research is required to establish causality, with the randomness assumption, our results qualify as causal enough to at least draw the attention of policymakers in the economic growth-chasing world.

\section{CONCLUDING REMARKS}

Our findings indicate positive correlation between international trade and pandemic death toll. For every additional $1 \%$ contribution of trade in GDP of the country, per capita death toll goes up by 0.428 . This finding has serious repercussions in the era of globalization.

Our findings are in agreement with findings of recent nCOVID death toll across the world. Top 5 countries (as on 15th April2020) by death toll are USA, Italy, Spain, France and UK and their healthcare expenditure as percentage of 
GDP is $17 \%, 9 \%, 9 \%, 11 \%$ and $10 \%$ respectively. While countries with less than 10 deaths (as on 15th April.2020) like Singapore, Sri Lanka, Qatar and Venezuela have relatively lower healthcare expenditure as percentage of GDP $14 \%$, $4 \%, 3 \%$ and $1 \%$ respectively).

We draw two policy implications:

1. Countries, which have their economies heavily reliant upon trade, need to take special safeguards against pandemic outbreaks.

2. Countries need to redesign their health care expenditure so as to cope with the pandemics. Apart from primary secondary and tertiary healthcare, fourth dimension of pandemic healthcare need to be institutionalized.

It has been recognised that response to pandemics has to be globalised [54] as characterised by the concept of 'One Health' .[55] Thus our findings need appreciation by both academics and policy makers while long term strategies are being formulated in the wake of the nCOVID crisis. There is a procedurally established system of 'health inquiries' the importance of which was highlighted by [56] and empirical evidence like the one brought out in this study will help in taking the inquiry further.

\section{References}

1. Worldometer. Coronavirus Update (Live): 315,267 Cases and 13,583 Deaths from COVID-19 Virus Outbreak - Worldometer [Internet]. 2020 [cited 2020 Mar 22]. Available from:

https://www.worldometers.info/coronavirus/

2. Jordà Ò, Singh SR, Taylor AM. Longer-run Economic Consequences of Pandemics [Internet]. National Bureau of Economic Research; 2020 Apr [cited 2020 Apr 19]. (Working Paper Series). Report No.: 26934. Available from: http://www.nber.org/papers/w26934

3. M.D MBAO. Viruses, Plagues, and History: Past, Present and Future. Oxford University Press; 2009. 401 p.

4. Armenian HK. Epidemiology: A Problem-solving Journey. Am J Epidemiol. 2009 Jan 15;169(2):127-31.

5. Holmberg M. The ghost of pandemics past: revisiting two centuries of influenza in Sweden. Med Humanit. 2017 Sep 1;43(3):141-7.

6. Pal M, Berhanu G, Desalegn C, Kandi V, M P, G B, et al. Severe Acute Respiratory Syndrome Coronavirus-2
(SARS-CoV-2): An Update. Cureus J Med Sci [Internet]. 2020 Mar 26 [cited 2020 Apr 18];12(3). Available from: https://www.cureus.com/articles/29589-severe-acuterespiratory-syndrome-coronavirus-2-sars-cov-2-anupdate

7. Grossman GM, Helpman E. Trade, knowledge spillovers, and growth. Eur Econ Rev. 1991 Apr $1 ; 35(2): 517-26$.

8. $M L, D M, K K, B F, L L, A G$. International trade drives biodiversity threats in developing nations. Nature. 2012 Jun 6;486(7401):109-12.

9. Frankel JA, Rose AK. Is Trade Good or Bad for the Environment? Sorting Out the Causality. Rev Econ Stat. 2005 Feb 1;87(1):85-91.

10. Dollar D. Is globalization good for your health? Bull World Health Organ. 2001; 79:827-33.

11. Ehrlich PR, Holdren JP. Impact of Population Growth. Science. 1971;171(3977):1212-7.

12. Rahman MM. Do population density, economic growth, energy use and exports adversely affect environmental quality in Asian populous countries? Renew Sustain Energy Rev. 2017 Sep 1; 77:506-14.

13. Giannoni M, Hitiris T. The regional impact of health care expenditure: the case of Italy. Appl Econ. 2002 Sep 1;34(14):1829-36.

14. Hadian M, Shojaee S, Rajabzadeh D. The impact of health expenditure on the economic growth in IRAN (1980-2004). J Health Adm. 2006 Jul 10;9(24):39-44.

15. Nixon J, Ulmann P. The relationship between health care expenditure and health outcomes. Eur J Health Econ. 2006 Mar 1;7(1):7-18.

16. Garrett L. The Next Pandemic? Foreign Aff. $2005 ; 84(4): 3-23$.

17. Taubenberger JK, Kash JC. Influenza Virus Evolution, Host Adaptation, and Pandemic Formation. Cell Host Microbe. 2010 Jun 17;7(6):440-51.

18. Kilbourne ED. Influenza Pandemics of the 20th Century. Emerg Infect Dis. 2006 Jan;12(1):9-14.

19. Schwartz B, Gellin B. Vaccination Strategies for an Influenza Pandemic. J Infect Dis. 2005 Apr 15;191(8):1207-9.

20. Ingram A. The New Geopolitics of Disease: Between Global Health and Global Security. Geopolitics. 2005 Oct 1;10(3):522-45.

21. Crisp LN. One World Health: An Overview of Global Health. CRC Press; 2016. 323 p. 
22. Taubenberger JK, Morens DM. 1918 Influenza: the Mother of All Pandemics. Emerg Infect Dis. 2006 Jan;12(1):15-22.

23. Levine DI, Rothman D. Does trade affect child health? J Health Econ. 2006 May 1;25(3):538-54.

24. Jaax J. Administrative Issues Related to Infectious Disease Research in the Age of Bioterrorism. ILAR J. 2005 Jan 1:46(1):8-14.

25. YU J, Lv X, Yang Z, Gao S, Li C, Cai Y, et al. The Main Risk Factors of Nipah Disease and Its Risk Analysis in China. Viruses. 2018 Oct;10(10):572.

26. Adda J. Economic Activity and the Spread of Viral Diseases: Evidence from High Frequency Data. Q J Econ. 2016 May 1;131 (2):891-941.

27. Hunt ME. AIDS: Globalization and Its Discontents. Zygon®. 2004;39(2):465-80.

28. Altman D. Globalization, Political Economy, and HIV/AIDS on JSTOR [Internet]. 1999 [cited 2020 Apr 17]. Available from:

https://www.jstor.org/stable/3108562? seq=1 \#metadat a_info_tab_contents

29. Kieh GK, Jr. Africa and the New Globalization. Routledge; 2016. 207 p.

30. Hosseini P, Sokolow SH, Vandegrift KJ, Kilpatrick AM, Daszak P. Predictive Power of Air Travel and SocioEconomic Data for Early Pandemic Spread. PLOS ONE [Internet]. 2010 Sep 15 [cited 2020 Apr 17];5(9).

Available from:

https://www.ncbi.nlm.nih.gov/pmc/articles/PMC2939 898/

31. Yilmazkuday H. Coronavirus Disease 2019 and the Global Economy [Internet]. Rochester, NY: Social Science Research Network; 2020 Mar [cited 2020 Mar 22]. Report No.: ID 3554381. Available from: https://papers.ssrn.com/abstract=3557327

32. Gibbs WW, Soares C. Preparing for a Pandemic. Sci Am. 2005;293(5):44-54.

33. Osterholm MT. Unprepared for a Pandemic. Foreign Aff. 2007; 86:47.

34. Enemark C. Pandemic pending. Aust J Int Aff. 2006 Mar 1;60(1):43-9.

35. Osterholm MT. Preparing for the Next Pandemic. N Engl J Med. 2005 May 5;352(18):1839-42.

36. Billmeier A, Nannicini T. Trade Openness and Growth: Pursuing Empirical Glasnost. IMF Staff Pap. 2009;56(3):447-75.
37. Floret N, Viel J-F, Mauny F, Hoen B, Piarroux R. Negligible Risk for Epidemics after Geophysical Disasters. Emerg Infect Dis. 2006 Apr;12(4):543-8.

38. Constantinescu C, Mattoo A, Ruta M. The Global Trade Slowdown: Cyclical or Structural? World Bank Econ Rev. 2020 Feb 1;34(1):121-42.

39. Reeves A, McKee M, Basu S, Stuckler D. The political economy of austerity and healthcare: Cross-national analysis of expenditure changes in 27 European nations 1995-2011. Health Policy. 2014 Mar 1;115(1):18.

40. Payal Hathi Sabrina Haque Lovey Pant Diane Coffey Dean Spears. Place and Child Health: The Interaction of Population Density and Sanitation in Developing Countries [Internet]. The World Bank; 2014 [cited 2020 Apr 19]. 47 p. (Policy Research Working Papers). Available from: https://elibrary.worldbank.org/doi/abs/10.1596/18139450-7124

41. Davoodi HR, Tiongson ER, Asawanuchit SS. Benefit Incidence of Public Education and Health Spending Worldwide: Evidence From A New Database. Poverty Public Policy. 2010;2(2):5-52.

42. Catchpole KR, Giddings AEB, Wilkinson M, Hirst G, Dale $T$, de Leval MR. Improving patient safety by identifying latent failures in successful operations. Surgery. 2007 Jul 1;142(1):102-10.

43. Berg-Beckhoff $G$, Blettner $M$, Kowall B, Breckenkamp J, Schlehofer B, Schmiedel S, et al. Mobile phone base stations and adverse health effects: phase 2 of a cross-sectional study with measured radio frequency electromagnetic fields. Occup Environ Med. 2009 Feb $1 ; 66(2): 124-30$.

44. Crown WH. Propensity-Score Matching in Economic Analyses: Comparison with Regression Models, Instrumental Variables, Residual Inclusion, Differencesin-Differences, and Decomposition Methods. Appl Health Econ Health Policy. 2014 Feb 1;12(1):7-18.

45. Golinelli D, Toscano F, Bucci A, Lenzi J, Fantini MP, Nante $N$, et al. Health Expenditure and All-Cause Mortality in the 'Galaxy' of Italian Regional Healthcare Systems: A 15-Year Panel Data Analysis. Appl Health Econ Health Policy. 2017 Dec 1;15(6):773-83.

46. Rhodes CJ, Anderson RM. Epidemic Thresholds and Vaccination in a Lattice Model of Disease Spread. Theor Popul Biol. 1997;2(52):101-18. 
47. Reperant LA, Osterhaus ADME. AIDS, Avian flu, SARS, MERS, Ebola, Zika... what next? Vaccine. 2017 Aug 16:35(35):4470-4.

48. Brewster AL, Lee S, Curry LA, Bradley EH. Association Between Community Social Capital and Hospital Readmission Rates. Popul Health Manag. 2018 May $31 ; 22(1): 40-7$.

49. Farag M, NandaKumar AK, Wallack S, Hodgkin D, Gaumer $G$, Erbil C. The income elasticity of health care spending in developing and developed countries. Int J Health Care Finance Econ. 2012 Jun $1 ; 12(2): 145-62$.

50. Simon JL. The Economics of Population Growth. Princeton University Press; 2019. 588 p.

51. Briggs DS. Progressing health reform through collaboration and community engagement. Asia Pac J Health Manag. 2017;12(3):5.

52. L S, K D. A structured epidemic model incorporating geographic mobility among regions. Math Biosci. 1995 Jul 1;128(1-2):71-91.

53. Glass LM, Glass RJ. Social contact networks for the spread of pandemic influenza in children and teenagers. BMC Public Health. 2008 Feb 14;8(1):61.

54. Mwacalimba KK. Globalised disease control and response distortion: a case study of avian influenza pandemic preparedness in Zambia. Crit Public Health. 2012 Dec 1;22(4):391-405.

55. Mwacalimba KK, Green J. 'One health' and development priorities in resource-constrained countries: policy lessons from avian and pandemic influenza preparedness in Zambia. Health Policy Plan. 2015 Mar 1;30(2):215-22.

56. Day GE, Casali GL. Do health inquiries lead to health system change? What have we learnt from recent inquiries and will the same mistakes happen again? Asia Pac J Health Manag. 2015;10(3):SI32. 